\title{
BOARDING TIME AND PATIENT SATISFACTION AT THE EMERGENCY DEPARTMENT
}

\author{
Waktu Pemindahan dan Kepuasan Pasien di Unit Gawat Darurat \\ *Uswatun Hasanah ${ }^{1}$, Nurul Jannatul Firdausi ${ }^{2}$ \\ ${ }^{1,2}$ Faculty of Health Science, Nahdlatul Ulama Surabaya University, Indonesia \\ *Correspondence: ana.km14@student.unusa.ac.id
}

\begin{abstract}
Background: Delays of inpatient transfer from the Emergency Department (ED) will affect delayed care, overcrowd at ED, and patient's disappointment. Such patient transfer delay from the Emergency Departement (ED) also occurs at Haji General Hospital, Surabaya.

Aims: This study analyzed the relationship between inpatient boarding time from Emergency Departement (ED) and patient satisfaction at Haji General Hospital, Surabaya.

Methods: This was an observational research using a cross-sectional approach. The population was 980 ED patients who decided to be hospitalized. Out of 980 ED patients, the study only involved 83 respondents selected by simple random sampling. The instruments used were observational sheet and questionnaires to collect data which were then analyzed with a chi-square test.

Results: Average boarding time was 142 minutes 25 seconds (minimum = 60 minutes; maximum $=290$ minutes). Almost all respondents (81.3\%) were satisfied about fast boarding time. Inpatient boarding time at the Emergency Departement (ED) was significantly related to patient satisfaction $(p=0.058<\alpha=0.1)$. The faster inpatients move to ED, the more satisfied they are.

Conclusion: The average patient boarding time from the Emergency Departement (ED) to Inpatient Unit was slow. Respondents were satisfied with the quality of services even though patient boarding time was slow. The hospital should pay more attention to evaluate the minimal standard of boarding time, ensure the availability of beds, and improve the quality of facilities and services to enhance patient satisfaction.
\end{abstract}

Keywords: Boarding time, Emergency Department, Inpatient, Satisfaction.

\section{ABSTRAK}

Latar Belakang: Keterlambatan transfer pasien rawat inap ke Instalasi Gawat Darurat (IGD) akan memengaruhi keterlambatan perawatan, terlalu padat di IGD akan menyebabkan kekecewaan pasien. Masalah keterlambatan transfer pasien dari Instalasi Gawat Darurat (IGD) ini juga terjadi di Rumah Sakit Umum Haji Surabaya.

Tujuan: Penelitian ini menganalisis hubungan antara waktu transfer rawat inap dari Instalasi Gawat Darurat (IGD) dan kepuasan pasien di Rumah Sakit Umum Haji Surabaya.

Metode: Penelitian observasional dengan pendekatan cross-sectional. Populasi berjumlah 980 yang berasal dari IGD yang memutuskan untuk dirawat di rumah sakit. Penelitian ini melibatkan 83 responden yang dipilih dengan simple random sampling. Instrumen yang digunakan adalah lembar observasi dan kuesioner. Data dianalisis dengan uji chi-square.

Hasil: Waktu pemindahan rata-rata adalah 142 menit 25 detik (minimum = 60 menit; maksimum = 290 menit). Hampir semua responden (81,3\%) menyatakan kepuasan ketika waktu transfer cepat. Waktu pemindahan untuk pasien rawat inap di Instalasi Gawat Darurat (IGD) secara signifikan terkait dengan kepuasan pasien $(p=0,058$ $<\alpha=0,1)$. semakin cepat waktu transfer dari IGD ke rawat inap, semakin puas pasiennya..

Kesimpulan: Hasil penelitian waktu rata-rata untuk memindahkan pasien dari Instalasi Gawat Darurat (IGD) ke unit rawat inap termasuk dalam kategori lambat. Responden mengatakan bahwa puas dengan kualitas pelayan, walaupun waktu tunggu untuk pasien pindahan lambat. Rumah sakit harus lebih memperhatikan evaluasi standar minimal waktu pemindahan, memperbaiki informasi ketersediaan tempat tidur, serta memperbaiki kualitas yang baik dalam fasilitas dan layanan untuk meningkatkan kepuasan pasien.

Kata kunci: Waktu pemindahan, UGD, Rawat inap, Kepuasan.

Received: 9 January $2019 \quad$ Accepted: 2 April 2019

Published: 23 September 2019

\section{INTRODUCTION}

Hospital is a health facility that provides health services to community. Under Law Number 44 of 2009 concerning hospitals, a hospital is defined as a health service institution that organizes individual health services in a comprehensive services, such as outpatient care, inpatient care, and emergency care. According to Law Number 44 of 2009 about Hospital, hospital is a complex organization that uses a combination of complex and specialized scientific equipment, functioned by a group of trained and 
educated personnel in dealing with problems related to modern medical knowledge for good health recovery and maintenance.

Hospitals become spearheads in health services, but not all hospitals in Indonesia have equal service standards and quality. Many more hospitals in Indonesia also receive high community demands for good facility and affordable health services. It means that hospitals must be approved to survive in the midst of tight competition among themselves to fulfill these demands. Therefore, it is essential for hospitals to provide excellent services every day in terms of outpatient care, nursing care, as well as emergency care (Pratiwi, 2016).

Emergency Department (ED) is one of service units at a hospital that provides first aid to treat patients with emergency and non-emergency conditions (Tambengi, Mulyadi and Kallo, 2017). The chaotic situation at ED is usually caused by high waiting time that eventually causes long queues and pressure service process. Long waiting in emergency rooms can be caused by patients who decide to be hospitalized but can not get a room. Registered patients, who cannot get a bed, have to wait for any other available beds. This situation may affect the capacity of the ED because patients moved to another room have to wait in the emergency room until a bed is available. Eventually, the ED cannot accept new patients anymore due to occupied beds. It may negatively impact the entire service process, such as complaints which affect patient satisfaction (Firdausi, 2016). Patients who have been treated for hospitalization will be transferred from the ED to the Inpatient Unit. Based on the medical records obtained from Haji General Hospital , inpatient visits from the ED in 2016 were 11,000 people while in 2017 there were 11,757 people (Performance Report of Haji General Hospital, 2017). Due to abundant patient visits, patients took long time to be transferred.

The length of waiting time is important to determine the quality of health services provided by a hospital. Based on the previous research, patients had to wait for about two to three hours before they were transferred to the inpatient room. Because of long waiting time, patients often complain for late transfer to the inpatient rooms (Pamungkas and Hariyanti, 2016). Patient satisfaction, therefore, plays an important role for measuring the quality of service at a hospital. Moreover, patient satisfaction gives loyalty to a hospital (Buhang, 2007). As seen from the case found at the Emergency Department of Haji General Hospital, this study aimed to analyze the relationship between boarding times for patient transfer from the ED and patient satisfaction at the Haji General Hospital, Surabaya.

\section{METHOD}

This study used an observational design with a cross-sectional method approach. Service processes from the ED to Inpatient Unit of Haji General Hospital, Surabaya were observed. The population of study was hospitalized patients in the ED who waited for any available beds. Using a simple random sampling technique, this study included 83 respondents. The respondents should meet the inclusion criteria, such as being hospitalized patients, coming from the ED, and going to be hospitalized in inpatient rooms of Haji General Hospital. The exclusion criteria involved patients who did not wait to be transferred to the inpatient room, were reffered to another hospital, and had worse medical conditions. The instruments of data collection were observation sheet and questionaires, and the data were analyzed with a chi-square test.

\section{RESULTS AND DISCUSSION}

\section{Respondent Characteristics}

Respondent characteristics include age, gender, education, job, and payment methods. Most of the respondents are between 26 and 45 years old (Adults) and are dominated by women. The majority of respondents have middle education. Mostly they are housewives. In terms of payment method, most of them use National Health Insurance or Jaminan Kesehatan Nasional (JKN) (see Table 1).

\section{Boarding Time}

The average time to move from the ED to inpatient rooms was about 142.42 minutes or 2.3 hours at 60 minutes minimumly and 290 minutes maximumly. Patients with private insurance and National Health Insurance spent different length of boarding time due to different administrative admission process to inpatient room. The administration for patients who paid with private insurancewas more concise than that for patients with National Health Insurance. The average of boarding time for patients with National Health Insurance is longer (147.78 minutes) than those with private insurance/ (134.48 minutes). About $60 \%$ of patients with National Health Insurance and private insurance payment spent long boarding time (see Table 2).

\section{Patient Satisfaction}

The results show 65 patients (78.3\%) transferred from the ED to inpatient room were satisfied with services at the Haji General Hospital, Surabaya. Satisfaction is measured according to 5 dimensions, namely Tangibles, Empathy, Reliability, Responsiveness, and Assurance. Patient satisfaction under $80 \%$ were in the aspects of Responsiveness $(77.40 \%)$ and Reliability $(79.27 \%)$. However, 18 respondents $(21.7 \%)$ were not satisfied with the boarding time for patient transfer. There are 3 aspects that make patients dissatisfied. They are certainty of time movement to inpatient room (assurance), information of bed availability (realibility), and speed of patient movement to inpatient room (responsiveness) (see Figure 1).

The officers were responsive while serving the needs of patients in the administration or registration section. Being responsive means being polite and friendly to each customer. However, the officers are not responsive enough in finding rooms, so patients have to wait for a long time to get a bed. After completing the administration and conducting laboratory tests, patients wait to get a bed. After patients are offered a room, they will be transferred from the emergency room to the inpatient room. The 
nurse or nurse assistant who is responsible to move the patient has to pay attention to patient safety.

Table 1. Characteristics of Respondents Transferred from Emergency Department of Haji General Hospital, Surabaya in 2018.

\begin{tabular}{|c|c|c|c|}
\hline No. & Characteristics & $\begin{array}{c}\text { Frequency } \\
\text { (n) }\end{array}$ & $\begin{array}{c}\text { Percentage } \\
(\%)\end{array}$ \\
\hline \multirow[t]{5}{*}{1.} & Age & & \\
\hline & Teenage & 7 & 8.4 \\
\hline & Adult & 45 & 54.2 \\
\hline & Elderly & 29 & 34.9 \\
\hline & Seniors & 2 & 2.4 \\
\hline \multirow[t]{3}{*}{2.} & Gender & & \\
\hline & Man & 27 & 32.5 \\
\hline & Woman & 56 & 675 \\
\hline \multirow[t]{5}{*}{3.} & Education & & \\
\hline & $\begin{array}{l}\text { Elementary } \\
\text { education }\end{array}$ & 16 & 19.3 \\
\hline & $\begin{array}{l}\text { Middle } \\
\text { education }\end{array}$ & 48 & 57.8 \\
\hline & $\begin{array}{l}\text { Higher } \\
\text { education }\end{array}$ & 18 & 21.7 \\
\hline & No education & 1 & 1.2 \\
\hline \multirow[t]{8}{*}{4.} & Job & & \\
\hline & $\begin{array}{l}\text { Employees in } \\
\text { the private } \\
\text { sector }\end{array}$ & 22 & 26.5 \\
\hline & Entrepreneurs & 17 & 20.5 \\
\hline & Housewife & 33 & 39.8 \\
\hline & Students & 1 & 1.2 \\
\hline & Teachers & 5 & 6.0 \\
\hline & $\begin{array}{l}\text { Government } \\
\text { employees }\end{array}$ & 3 & 3.6 \\
\hline & Retired & 2 & 2.4 \\
\hline \multirow[t]{3}{*}{5.} & $\begin{array}{l}\text { Payment } \\
\text { Method }\end{array}$ & & \\
\hline & $\begin{array}{l}\text { National Health } \\
\text { Insurance }\end{array}$ & 56 & 67.5 \\
\hline & $\begin{array}{l}\text { Private } \\
\text { Insurance }\end{array}$ & 27 & 32.5 \\
\hline
\end{tabular}

The study found that boarding time (76.5\%) was slow at $>120$ minutes. Meanwhile, patients and their familywere satisfied with the quality of regular service given even though the boarding time for patient transfer was fairly long. The service responsiveness provided by the hospital is quicker than at others, and facilities at the hospital are enough. The highest patient satisfaction is about tangible dimension (84.93\%), meaning patients thought facilities for boarding patients in the ED are good and comfortable. In addition, the hospital also provides flow of service information. The high satisfaction with tangible dimension can suppress patient dissatisfaction.

Self-satisfaction is assessed based on five dimensions of service quality, such as tangibles or physical appearance, empathy, reliability, responsiveness, and assurance ( Satrianegara, 2014). Based on Figure 1, it can be concluded that out of 5 dimensions of service quality, tangible aspect has the highest value with the percentage of $84.93 \%$, and the lowest value was responsiveness aspect with the percentage of $77.40 \%$.

Table 2. Cross Tabulation on Types of Boarding Patients at the Emergency Department of Haji General Hospital, Surabaya in 2018.

\begin{tabular}{lc|cc}
\hline \multirow{2}{*}{$\begin{array}{c}\text { Types of } \\
\text { Patients }\end{array}$} & \multicolumn{2}{c}{ Boarding Time } & Total \\
\cline { 2 - 4 } & $\begin{array}{c}\text { Quick } \\
(\leq 120 \text { minutes })\end{array}$ & $\begin{array}{c}\text { Slow } \\
(>120 \text { minutes })\end{array}$ & \\
\hline $\begin{array}{l}\text { National Health } \\
\text { Insurance }\end{array}$ & 20 & 36 & 56 \\
\hline Private Isurance & 12 & 15 & 27 \\
\hline Total & 32 & 51 & 83 \\
\hline
\end{tabular}

Table 3. Patient Satisfaction at the Emergency Department of Haji General Hospital, Surabaya in 2018

\begin{tabular}{cccc}
\hline No. & $\begin{array}{c}\text { Patient } \\
\text { Satisfaction }\end{array}$ & $\begin{array}{c}\text { Frequency } \\
(\mathbf{n})\end{array}$ & $\begin{array}{c}\text { Percentage } \\
(\%)\end{array}$ \\
\hline 1. & Satisfied & 65 & 78.3 \\
\hline 2. & Unsatisfied & 18 & 21.7 \\
\hline & Total & 83 & 100.0 \\
\hline
\end{tabular}

Out of 83 transferred patients from emergency room to inpatient room, there were 26 patients $(18.8 \%)$ who stated that boarding time was fast. Whereas, 39 respondents dissatisfied because of slow boarding time. Other sixrespondents (18.8\%) were dissatisfied with boarding time for fast transfer, and 12 respondents $(23.5 \%)$ were not satisfied with transfer boarding time. The results of cross tabulation (Contionous Correction) show that $p$-value is 0.058 , meaning $\mathrm{HO}$ is rejected because $\mathrm{p}$-value is less than a-value of 0.1 (See Table 4).

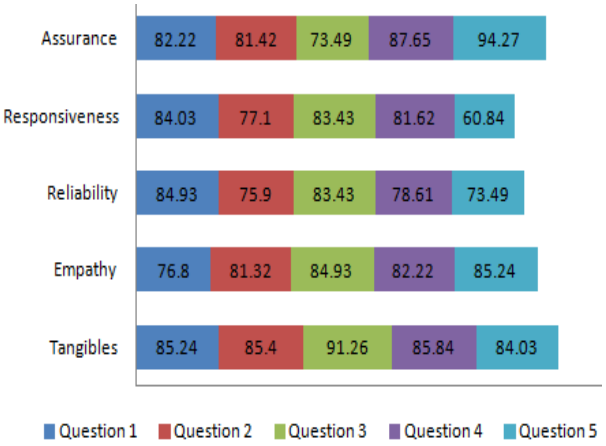

Figure 1. Five Dimensions of Patient at the Emergency Department of Haji General Hospital, Surabaya.

Based on the research conducted by Jacobis at District General Hospital of Prof. Dr. R. D. Kandou Manado, responsiveness affects patient satisfaction (Jacobis, 2013). Likewise, a study conducted by Muliaty (2016), tangibles can affect the quality of service. It was in line with the research conducted by Canadian Institute for Health Information (2007), which analyzed boarding time at 277 hospitals in the world.

The investigation found out that boarding time spent to find an available bed at the Emergency Department of the hospitals was $\leq 2$ hours. Long 
boarding time was caused by long administrative processes, such as medical record in the registration or admission counter, increase of patient visits at the ED, and long boarding time according to patient condition (Canadian Institute for Health Information, 2007). Similarly, this current study found the relationship between boarding time and patient satisfaction. Patient satisfaction could also be influenced by the staff's hospitality and service speed (Kristiani, Sutriningsih and Ardiyani, 2017).

In Table 1, the characteristics of respondents based on age are mostly adults (54.2\%) aged 26-45 years. In terms of gender, most of them are females $(67.5 \%)$, and the majority of the respondents graduated from middle education $(57.8 \%)$. Almost half of them (39.8\%) are housewives, and they mostly use National Health Insurance to pay the healthcare cost $(67.5 \%)$.

The average boarding time for transferred patients from the ED to the inpatient room is 142 minutes. The minimum boarding time is 60 minutes, and the maximum boarding time is 290 minutes. Patients with private insurance/ (Non-NHI) and patients with National Health Insurance (NHI) certainly have different transfering time. Those with private insurance (Non-HNI) have less average transfering time. Despite long boarding time, 65 respondents were mostly satisfied with the quality of services.

Table 4. Relationship between Transfer Boarding Time to Inpatient Rooms and Patient Satisfaction at Haji General Hospital, Surabaya in 2018.

\begin{tabular}{|c|c|c|c|c|c|c|c|}
\hline \multirow{3}{*}{ Boarding Time } & \multicolumn{4}{|c|}{ Patient satisfaction } & & & \multirow{3}{*}{ P-Value } \\
\hline & \multicolumn{2}{|c|}{$\begin{array}{c}\text { Satisfied } \\
(\geq 75)\end{array}$} & \multicolumn{2}{|c|}{$\begin{array}{c}\text { Unsatisfied } \\
(<75)\end{array}$} & \multicolumn{2}{|c|}{ Total } & \\
\hline & $\mathbf{N}$ & $(\%)$ & $\mathbf{N}$ & $(\%)$ & $\mathbf{N}$ & (\%) & \\
\hline$\leq 120$ minute (Quick) & 26 & 81.3 & 6 & 18.8 & 32 & 100.0 & \\
\hline$>120$ minutes (Slow) & 39 & 76.5 & 12 & 23.5 & 51 & 100.0 & 0.058 \\
\hline Total & 65 & 78.3 & 18 & 21.7 & 83 & 100.0 & \\
\hline
\end{tabular}

Based on Table 4, it shows that out of 32 respondents choosing fast category boarding time, almost all $(81.3 \%)$ said they were satisfied. Out of 51 respondents who considered moderate-category transfering time, almost all (76.5\%) were satisfied.

Seen from 39 patients who considered slow waiting time, almost all (76.5\%) were satisfied even though the boarding time was slow. However, 6 respondents who experienced fast waiting time $(18.8 \%)$ were not satisfied. Therefore, waiting time is not the only factor that contributes to satisfaction, but there are other factors as well.

\section{CONCLUSION}

The average waiting time for patients at the Emergency Departement (ED) of Haji General Hospital, Surabaya was 142.42 minutes or 2.3 hours. Therefore, it can be considered as slow. Almost all respondents were satisfied with the quality of services even though transfer waiting time was slow. There was a relationship between waiting time from the ED to the inpatient room and patient satisfaction at Haji General Hospital, Surabaya. It is recommended that the hospital management should pay attention on the transferring process from the ED to inpatient room in order to improve patient satisfaction.

\section{REFERENCES}

Burhan, B. (2007) Metode Penelitian Kuantitatif. Jakarta: Kencana Prenada Media Group.

Canadian Institute for Health Information (2007) Understanding Emergency Department Wait Times. Ontario. Available at: https://secure.cihi.ca/free_products/Emergen cy_Department_Wait_Times_III_2007_e.pdf.

Firdausi, $\bar{N}$. J. (2016) Analisis Waktu Tunggu Pasien yang di Rujuk ke Rawat Inap Melalui Instalasi Gawat Darurat (IGD) RSUD DR. Moewardi. Universitas Gadjah Mada. Available at: http://etd.repository.ugm.ac.id/index.php?mo $\mathrm{d}=$ penelitian_detail\&sub=PenelitianDetail\&ac $\mathrm{t}=\mathrm{view} \& \mathrm{typ}=\overline{\mathrm{h}} \mathrm{tm} \mid \&$ buku_id=95558\&obyek_id $=4$

General Hospital of Haji (2017) Performance Report of General Hospital of Haji. Surabaya.

Jacobis, R. (2013) 'Faktor-Faktor Kualitas Pelayanan Pengaruhnya Terhadap Kepuasan Pasien Rawat Inap Peserta Jamkesmas di BLU RSUP Prof. Dr. R. D. Kandou Manado', Jurnal $E M B A, 1(4)$, pp. 619-629.

Kristiani, Y., Sutriningsih, A. and Ardiyani, V. M. (2017) 'Hubungan Waiting Time dengan Kepuasan Pasien Prioritas 3 di Instalasi Gawar Darurat RS Panti Waluyo Sawahan Malang', Nursing News, 2(2), pp. 163-168.

Muliaty (2016) 'Faktor-Faktor yang Mempengaruhi Kualitas Pelayanan pada Politeknik Negeri Media Kreatif Makassar', Jurnal Administrasi Publik, 6(1), pp. 77-82.

Pamungkas, F. et al. (2016) 'Pengalaman Pasien Dirawat Inap di Rumah Sakit sebagai Upaya Penyusunan Strategi Pemasaran', Jurnal Aplikasi Manajemen, 14(1), pp. 109-119.

Pratiwi, M. (2016) 'Pengaruh Mutu Pelayanan Kesehatan terhadap Loyalitas Pasien RSUD Raden Mattaher Jambi 2016', Scientia Journal, 5(1), pp. 31-38.

Satrianegara, M. F. (2014) Organisasi dan Manajemen Pelayanan Kesehatan: Teori dan Aplikasi dalam Pelayanan Puskesmas dan Rumah Sakit. Surabaya: Salemba Medika.

Tambengi, H., Mulyadi, N. and Kallo, V. (2017) 'Hubungan Waktu Tunggu dengan Kecemasan Pasien di Unit Gawat Darurat 
RSU GMIM Pancaran Kasih Manado', Jurnal Keperawatan, 5(1). 